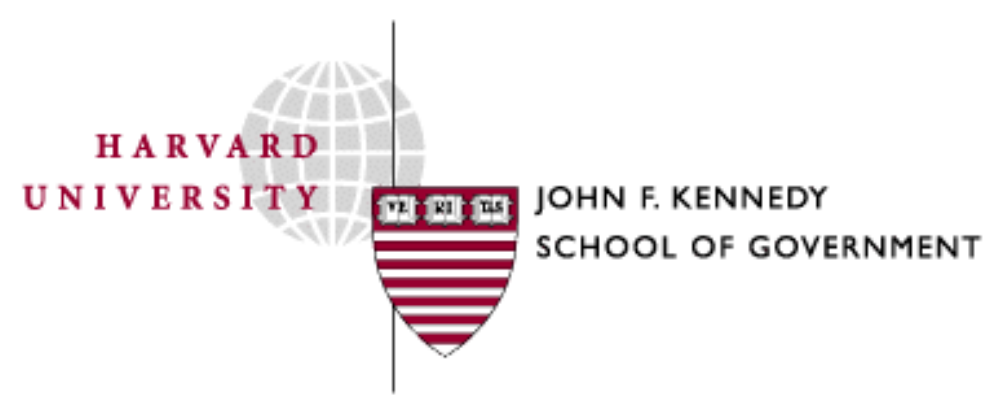

Faculty Research Working Papers Series

\title{
Myths And Realities of Tribal Sovereignty: The Law And Economics of Indian Self-Rule
}

Joseph P. Kalt and Joseph William Singer

March 2004

RWP04-016

The views expressed in the KSG Faculty Research Working Paper Series are those of the author(s) and do not necessarily reflect those of the John F. Kennedy School of Government or Harvard University. Copyright belongs to the author(s). Papers may be downloaded for personal use only. 
MYTHS AND REALITIES OF TRIBAL SOVEREIGNTY: THE LAW AND ECONOMICS OF INDIAN SELF-RULE

Joseph P. Kalt

John F. Kennedy School of Government

Harvard University

and

Joseph William Singer

Harvard Law School

Harvard University

NATIVE ISSUES RESEARCH SYMPOSIUM

Harvard University

December 4-5, 2003 (revised January 2004)

Sponsored by the HaRvard University Native American Program SUPPORTED BY THE ERNST FUND FOR NATIVE AMERICAN STUDIES www.ksg.harvard.edu/hunap 


\title{
Abstract \\ MYTHS AND REALITIES OF TRIBAL SOVEREIGNTY: THE LAW AND ECONOMICS OF INDIAN SELF-RULE
}

\author{
Joseph P. Kalt \\ and \\ Joseph William Singer ${ }^{*}$
}

The last three decades have witnessed a remarkable resurgence of the American Indian nations in the United States. The foundation of this resurgence has been the exercise of self-government - sovereignty - by the more than 560 federally-recognized tribes in the U.S. In this study, we explore legal and economic dimensions of current perceptions of and debates over the nature and extent of tribal self-rule in the United States. Our objective is to clarify and illuminate by distinguishing between myth and reality. We address key threads of thought and assumption that pervade, accurately or inaccurately, discussions in the public policy arena. What emerges is a picture in which tribes do exercise substantial, albeit limited, sovereignty. This sovereignty is not a set of "special" rights. Rather, its roots lie in the fact that Indian nations pre-exist the United States and their sovereignty has been diminished, but not terminated. Tribal sovereignty is recognized and protected by the U.S. Constitution, legal precedent, and treaties, as well as applicable principles of human rights.

* Prof. Kalt is the Ford Foundation Professor of International Political Economy, John F. Kennedy School of Government, Harvard University. He also serves as faculty chair of the Harvard University Native American Program (HUNAP) and co-director of the Harvard Project on American Indian Economic Development (www.ksg.harvard.edu/hpaied). Prof. Singer is Professor of Law, Harvard Law School, Harvard University and a member of HUNAP's Faculty Advisory Board. The authors gratefully acknowledge the helpful comments of Sanjeev Khagram and participants in the Native Issues Research Symposium, as well as the financial support of the HUNAP's Ernst Fund for Native American Studies. 


\title{
MYTHS AND REALITIES OF TRIBAL SOVEREIGNTY: THE LAW AND ECONOMICS OF INDIAN SELF-RULE
}

\author{
Joseph P. Kalt \\ and \\ Joseph William Singer
}

\section{Introduction: A Critical Point in the Course of Indian Self-Rule}

The last three decades have witnessed a remarkable resurgence of the Indian nations in the United States. After centuries of turmoil, oppression, attempted subjugation, and economic deprivation, the Indian nations have asserted their rights and identities, have built and rebuilt political systems in order to implement self-rule, and have begun to overcome what once seemed to be insurmountable problems of poverty and social disarray. The foundation of this resurgence has been the exercise of selfgovernment by the more than 560 federally-recognized tribes in the U.S.

Supported by every U.S. President since the 1960s and bolstered, for a time, by a combination of federal court rulings and congressional policies, tribal self-rule sovereignty - has proven to be the only policy that has shown concrete success in breaking debilitating economic dependence on federal spending programs and replenishing the social and cultural fabric that can support vibrant and healthy communities and families. ${ }^{1}$ While gaming enterprises of tribes’ governments garner most of the attention, self-rule is creating more and more economic success stories in Indian

1 This conclusion emanates from an extensive and growing body of research, particularly that associated with the Harvard Project on American Indian Economic Development. For example, on economic development, see: Cornell and Kalt (1992, 1995, 1997a, 1997b, 1998, 2000); Jorgensen (1997, 2000a, 2000b); Krepps (1992); Krepps and Caves (1994). On social conditions and health, see, for example, Adams (1999); Dixon, et al. (1998); Moore, et al. (1990); Costello, et al. (2003). 
Country - from the virtual elimination of tribal unemployment and the boom in nonIndian hirings in the factories and other operations of the Mississippi Choctaw, ${ }^{2}$ to the cutting of unemployment from $70 \%$ to $13 \%$ in six years via the non-gaming businesses of the Winnebago Tribe's (Nebraska) Ho-Chunk Inc. ${ }^{3}$ Gaming success itself is spurring self-sufficiency, as tribes such as Oneida (New York) and Mille Lacs (Minnesota) take the step of eschewing federal funding. And the success of self-determination is not solely economic - as when Mississippi Choctaw plows the fruits of economic development into dramatic improvements in public safety and health care delivery, ${ }^{4}$ Mille Lacs is able to invest in award-winning efforts to replenish Native language use, ${ }^{5}$ and Jicarilla Apache (New Mexico) and White Mountain Apache (New Mexico) are able to take control of wildlife and forest management with professionalism and results perhaps unmatched by any government anywhere. ${ }^{6}$

Despite - or, perhaps, because of - the economic, social and political success of Native self-rule, tribal sovereignty is now under increasingly vigorous and effective

2 Ferraro (1998).

3 Harvard Project on American Indian Economic Development, "Economic Development Corporation, Ho-Chunk Inc., Winnebago Tribe of Nebraska," Tribal Governance Success Stories: Honoring Nations 2000.

4 Harvard Project on American Indian Economic Development, "Choctaw Health Center, Mississippi Choctaw,” Tribal Governance Success Stories: Honoring Nations 1999; Harvard Project on American Indian Economic Development, "Choctaw Community Injury Prevention Program, Mississippi Choctaw" and "Family Violence \& Victim's Services, Mississippi Choctaw," Tribal Governance Success Stories: Honoring Nations 2003.

5 Harvard Project on American Indian Economic Development, "Ojibwe Language Program, Mille Lacs Band,” Tribal Governance Success Stories: Honoring Nations 2000.

6 Harvard Project on American Indian Economic Development, "Wildlife and Fisheries Management Program, Jicarilla Apache Tribe,” Tribal Governance Success Stories: Honoring Nations 1999; Harvard Project on American Indian Economic Development, "White Mountain Apache Wildlife and Recreation Program,” Tribal Governance Success Stories: Honoring Nations 2000. 
attack. Over the last decade in particular, the Supreme Court has moved repeatedly to limit tribal powers over nonmembers. Lower courts have fed this process with decisions that increasingly rein in the ability of tribal governments to govern commerce and social affairs on their reservations. ${ }^{7}$ Congress, too, has seen increasing numbers of bills introduced to abolish the tribes' sovereign immunity, limit their taxation powers, and regulate their commerce. ${ }^{8}$ The well-known Indian Gaming Regulatory Act of 1988, so widely credited by mainstream media with fostering rising incomes on a number of reservations, in fact, imposed limits on tribes' sovereignty that had been secured in 1987 with the Supreme Court's ruling in California v. Cabazon Band of Mission Indians. ${ }^{9}$ State and local governments similarly are pushing back against assertions by tribes of tribes' governing authority. ${ }^{10}$

Indian nations have re-entered the consciousness of the general public and the media, and many are left wondering why tribes have "suddenly" become regional political forces and, increasingly, economic engines. To many non-Indians, Indians are seen as legitimate only to the extent that they fill those non-Indians' stereotypes: If Indians are poor or "authentic", they may deserve federal handouts, perhaps as compensation for conquest, but if they are wealthy and modern, why do they continue to enjoy "special” rights? Similarly, tribes as collectives are seen by many non-Indians as legitimate if they act like private clubs, but not if they act like sovereigns. Non-Indians

\footnotetext{
7 For a useful summary, see Wilkins ( 2002), esp. at 92-96.

$8 \quad$ Wilkins (2002) at 78-81.

9 California v. Cabazon Band of Mission Indians, 480 U.S. 202 (1987).

10 Wilkins (2002) at 94-102.
} 
are often confused when tribes claim to be “nations.” Don't they know that they have been absorbed by the United States? Weren't the tribes conquered long ago? The fact that non-Indians can ask these questions reflects a failure of understanding of U.S. history and law. Tribes are sovereigns; if they are private clubs, they are private clubs with their own jails.

In this study, we explore legal and economic dimensions of current perceptions of and debates over the nature and extent of tribal self-rule in the United States. Our objective is to clarify and illuminate by distinguishing between myth and reality. We address what we believe are key threads of thought and assumption that pervade, accurately or inaccurately, discussions in the public policy arena. What emerges is a picture in which tribes do exercise substantial, albeit limited, sovereignty. This sovereignty is not a set of "special" rights. Rather, its roots lie in the fact that Indian nations pre-exist the United States and their sovereignty has been diminished but not terminated. Tribal sovereignty is recognized and protected by the U.S. Constitution, legal precedent, and treaties, as well as applicable principles of human rights.

Tribal sovereignty is not just a legal fact; it is the life-blood of Indian nations. This is obviously true in the political sense: Without self-rule, tribes do not exist as distinct political entities within the U.S. federal system. Moreover, economically and culturally, sovereignty is a key lever that provides American Indian communities with institutions and practices that can protect and promote their citizens' interests and wellbeing. Without that lever, the social, cultural, and economic viability of American Indian communities and, perhaps, even identities is untenable over the long run. 


\section{Defining "Sovereignty"}

The concept of "sovereignty" can, and does, fill volumes of treatises in law, political science, and international relations. World economic and military affairs at the start of the $21^{\text {st }}$ Century are giving new salience to "sovereignty" - as terms like "nation building” are being used as uneasy foundations for remaking countries in the Middle East, Africa, and elsewhere; as developed countries debate how much power to relinquish to transnational judicial bodies such as the World Trade Organization and the World Court; and as some in smaller nations worry themselves about the loss of "cultural sovereignty" to the juggernaut of media-based U.S. pop culture. The sources, meanings, consequences, limits, propriety, and other fine points of "sovereignty" seem destined to be widely and vigorously discussed, dissected, and debated for years to come.

This is no less true when it comes to Indian sovereignty. But here we adopt the most straightforward of definitions of "sovereignty". Sovereignty is self-rule. As applied to Indian Country, sovereignty boils down to: Who is going to decide what constitution we will operate under? Who will decide what environmental rules will govern? Who will decide whether that natural resource gets developed? Who decide if a gaming casino is opened? Who will decide what is taught in the reservation high school? Who will decide what taxes are collected and from whom? Who can regulate and enforce contracts, provide remedies for negligent conduct, and adjudicate disputes over property? Who will decide the speed limit on the road into the tribal headquarters? Who will decide how to decide questions such as these? When the answer to questions of these types - and particularly the last question - is "the Tribe" (i.e., the tribal government), an 
Indian tribe has sovereignty. When the answer is "some non-Indian government", a tribe lacks sovereignty.

Of course, the foregoing does not even address the question of who should have sovereignty. As tribes have learned over the last several decades, however, there are important distinctions between de recto sovereignty, de jure sovereignty, and de facto sovereignty (i.e., sovereignty by moral principle or right, sovereignty by legal decree or legislative act, and sovereignty in practice). Tribes and their supporters can compellingly and articulately assert the first, and petition and lobby for the second, but what ultimately matters is the last form of sovereignty - the de facto exercise of sovereign powers. Indeed, as discussed below, armed with fierce commitment to the propriety of their de recto claims, the frontier for many tribes in today's legal and political environment lies in building the institutional and economic capacity to exercise self-rule even where its de jure foundations may be ambiguous or even absent. That is, many tribes increasingly embrace the Nike strategy of "just do it" when it comes to matters ranging from the enforcement of environmental codes to the administration of justice in contract disputes to the regulation of foster care placements for their citizens. ${ }^{11}$ They are exercising sovereignty. When they do this, they create facts on the ground that can give tribes' sovereignty a firm foundation; at the same time, the de facto exercise of sovereignty creates a backlash that may threaten these newfound gains.

If defining "sovereignty" as self-rule is straightforward, understanding the sources, state, and consequences of tribal sovereignty is not. Instead, such matters are

11 Cornell and Kalt (1992, 1998). 
subject to widespread misunderstanding among Indians and non-Indians, alike. Let us examine the contours of tribal sovereignty and its relation to state and federal sovereignty. We do so by addressing a series of stylized representations that are afoot in legal, political, and general public discussions of tribes and their rights.

\section{II.A Sources of Tribes' Sovereignty}

1. "American Indians were conquered and lost their sovereignty." Many assume that the United States conquered the Indian nations long ago and that any remnants of tribes' sovereignty are pleas to secede from the U.S. or to reverse an "irreversible" fact that the U.S. is the sole sovereign within its borders. Yet, the relationship between conquest and tribal sovereignty is multi-dimensional and variegated.

It is undoubtedly true that the United States (in the form of the federal government) can, and has, exercised de facto rule over both tribes and individual Indians without restraint and across all manner of human affairs. And, by its legal and constitutional standards, it has often exercised such rule de jure. When it has wanted to, for example, the United States has conscripted citizens of tribes into its armies, terminated the legal status of tribes and their property holdings, provided for law and order in communities of Native individuals, protected tribes from the exercise of sovereignty over tribal citizens by other sovereigns within its borders (i.e., states and municipalities), authorized the exercise of sovereignty over tribal citizens by other sovereigns within its borders (i.e., states and municipalities); unilaterally determined the applicability of its tax levies on individual Indians and tribes, and engaged in all manner 
of other de facto exercises of U.S. sovereignty. In that sense, it is undeniable that the U.S. has, de facto, conquered the tribes within its borders.

This observation on the factual state of affairs, however, addresses neither the de recto nor the de jure boundaries of tribes' sovereignty vis-à-vis the federal government and vis-à-vis the other sovereigns operating within U.S. borders (i.e., the states and municipalities). It is not surprising that, throughout most of its history, ${ }^{12}$ the U.S. federal government has been notably equivocal about simply declaring itself the conqueror. Such a move never particularly troubled the Spanish conquerors of the Americas, but continues to sit uneasily, at best, with Anglo human right precepts recognizing primacy of “first in place, first in time.” While such doctrines (and related concepts of a people’s inherent rights of self-rule) are extralegal and have their roots reaching back at least to the Enlightenment philosophers, they continue to influence notions of the de recto rights of tribes and the U.S. de jure legal and legislative standards impinging on tribes' sovereignty. Thus, for example, the United States' Anglo-rooted cousins in Australia, New Zealand, and Canada have all recently found themselves ruling at the highest level that indigenous communities’ rights to at least land and resources, if not self-rule, are intact today in the absence of explicit "extinguishment of title” at some point in history. ${ }^{13}$ Similar concepts undergird U.S. recognition of Native land claims and compensation, as

12 But not all - as the Indian wars of, particularly, the second half of the $19^{\text {th }}$ Century illustrate.

13 Re: Canada, the key ruling came in Delgamuukw $v$ The Queen in Right of British Columbia, reported in 79 DLR ( $\left.4^{\text {th }}\right)$ 185; see, e.g., Allain (1996) and B.C. Treaty Commission (2003). Re: Australia, the key decision has been Mabo and Others v. Queensland (No. 2) (1992) 175 Clr 1 F.C. 92/014 (http://www.austlii.edu.au/cgi-bin/disp.pl/au/cases/cth/high_ct/unrep44.html?query=mabo). Re: New Zealand, see Te Weehi v Regional Fisheries Officer (1986) 1 N.Z.L.R. 682. 
well as policies that make federal recognition of tribes contingent upon demonstration of continuity to present times in the existence of a tribal polity.

The reality is that few tribes in the U.S. were conquered in military campaigns. Most, but not all, tribes entered treaties with the United States. This was particularly true of those that engaged in military combat with the U.S. The very act of treating is a nation-to-nation form of intergovernmental interaction, and the British-cum-Americans certainly saw such interaction as de recto and de jure more regularly than the Spanish or the Portuguese in the Americas. The resulting treaties did not and do not absorb the tribes into the United States; rather, the reverse is true. The treaties recognize and preserve tribal sovereignty: In return for giving up almost all the land in the U.S., the U.S. made promises to the tribes. ${ }^{14}$ It promised to respect their rights over reserved land ${ }^{15}$ and to recognize that those lands would be governed by tribes, not by the state governments. Those tribes that did not sign treaties were similarly protected by the doctrine that inherent sovereignty is to be respected by the United States. ${ }^{16}$

None of this is to say that the U.S. has been all sweetness and light in its dealings with the Indians. Far from it. But it is a crucial fact that, from the beginning, the United States recognized the existence of tribal governments. Though the U.S. has, at times, sought to end tribal governments, it has repeatedly returned to its "recognition of the inherent sovereignty of tribal governments" ${ }^{17}$ and rejected termination policies, returning

14 See U.S. Commission on Civil Rights (2003) at Chapter 1.

15 Hence, the term Indian "reservation”.

16 U.S. Commission on Civil Rights (2003) at Chapter 1.

17 U.S. Commission on Civil Rights (2003) at 2. 
to recognize the existence of Indian nations within the federal framework. This is the current policy of the United States, and has been so for forty years - to recognize tribes' sovereignty and to ensure its continued existence. This policy is based on promises made by the United States in its 250 treaties with Indian nations and is based on recognition of tribes’ sovereignty embedded in the U.S. Constitution.

2. "There can't be multiple sovereigns in the same geographic area." The U.S. system is a federal system. In a very real sense, its essence is the recognition of multiple sovereigns within its overall boundaries, and it uses a constitution to parse out the many different functions governments might perform and powers they might exert among its multiple sovereigns. Within the borders claimed by the federal government, the U.S. has more than four dozen states that exercise broad sovereign powers, ranging from taxation to speed limits, from criminal law to natural resource management. A number of these sovereigns are surrounded by sovereign neighbors and dwarfed in size by a number of Indian reservations. ${ }^{18}$ The federal government coexists with states, and the states coexist with each other, in a system in which states have certain powers and the federal government has certain powers. The Union has not come asunder because, for example, Massachusetts has decided to enter into the big-time gambling business with its state lottery, but Alabama has not. The U.S. survives notwithstanding the fact that Washington State has no income tax, while the U.S. and Oregon do.

There is no inherent contradiction in a federalist arrangement among multiple sovereigns and multiple layers. But sustaining such an arrangement does mean that the

18 The Navajo Nation, for example, is approximately equal in size to West Virginia, 24 times larger than Rhode Island, 12 times larger than Delaware, and 4 times larger than Hawaii. 
sovereign with the ultimate de facto power to impose its will (i.e., the federal government) is more or less continuously being pulled toward and away from doing so, and that the various sovereigns are under pressure to structure their intergovernmental relations so as to work out such differences and disputes as may arise while respecting each others' sovereignty in its proper range. In this regard, it is telling that tribes which push hardest on the limits of de jure and, especially, de facto sovereignty are commonly at the forefront of efforts to improve their intergovernmental relations with the federal government and with neighboring states, counties, and cities. The examples are numerous and growing - from the preeminence of the Nez Perce Tribe in the federalstate-tribal efforts to restore and protect gray wolf populations in the Rockies, ${ }^{19}$ to the Fond du Lac Band's work with local counties in building the Band's off-reservation child foster care system, ${ }^{20}$ to the Columbia River Inter-Tribal Fish Commission's work on salmon protection in the Pacific Northwest, ${ }^{21}$ to the many cross-deputization agreements between tribes and state and county law enforcement. ${ }^{22}$

3. “Tribal sovereignty means 'special' rights for Indians." Indians and tribes are sometimes seen as pleaders for "special rights.” Why should they have sovereignty and not comply with the laws the rest of us abide by? Why are they allowed to own casinos when non-Indians are not allowed to do so?

19 Harvard Project on American Indian Economic Development, "Idaho Gray Wolf Recovery Wildlife Program,” Tribal Governance Success Stories: Honoring Nations 1999.

20 Harvard Project on American Indian Economic Development, “Off-Reservation Indian Foster Care” Tribal Governance Success Stories: Honoring Nations 1999.

21 Harvard Project on American Indian Economic Development, "Columbia River Inter-Tribal Fish Commission,” Tribal Governance Success Stories: Honoring Nations 1999.

22 Oklahoma, alone, reports 89 cross-deputization agreements in the state. Oklahoma Indian Affairs Commission (2003). 
Of course, at one level, such questions contain their own contradictions to assertions that tribal sovereignty consists of special rights for Indians. The citizens of the sovereign State of Nevada (or State of Utah, or State of ...) are allowed to decide for themselves whether or not to allow casino gambling, or to have their state government own a gambling operation, or to make innumerable other choices affecting that state. And when the citizen of Ohio is driving on Ohio state roads, she doesn't have to abide by the traffic laws "the rest of us abide by" when driving on state roads in Massachusetts. And the New Hampshire resident earning his income in New Hampshire does not pay income taxes, much less income taxes in Vermont. Relative to Vermonters, that New Hampshire income earner may have "special” rights, but he does not enjoy special rights under New Hampshire's exercise of its sovereignty. Rather, he lives under the jurisdiction of New Hampshire as a sovereign. In so doing, neither he nor New Hampshire is denying Vermonters and Vermont the right to exercise their sovereign rights (e.g., over how and whom to tax).

4. "Indian Rights of Sovereignty Are Race-Based." It is sometimes argued that Indians are a race and that special rights for Indian nations constitute either a harmful form of racial segregation akin to the Jim Crow laws or a form of affirmative action based on race. Fishing rights, for example, are criticized as race-based special rights of access to federal lands. Gaming rights, actually emanating as rights of Indian nations from the U.S. Constitution's Commerce Clause (per California v. Cabazon Band of 
Mission Indians), are seen as a special kind of welfare program for people of Indian racial descent. $^{23}$

The reality is that tribal sovereignty is not based on race, but is a recognition of the numerous sovereign nations that were in the land settled by the European colonists. Federal law and treaties recognize tribal sovereignty and obligations to Indian nations, not to Indians as a racial group. Those de jure obligations rest, first and foremost, on treaties with nations. While some government programs and benefits go to Indians generally, and not just to Indian nations, this is partly based on the fact that the colonial process, with its severe disruption of tribal economies, land use patterns, and devastation through disease, resulted in taking over some tribal lands without a formal treaty with an existing government. As a result, a "federal trust responsibility is rooted in the U.S. government's obligation to compensate Native Americans" and "[t]he legal obligation is a matter of both moral and legal imperative." ${ }^{24}$ As for fishing, hunting and other resource-access rights, they are based on property rights reserved by Indian nations when they were convinced or forced to give up most of their property. Resource-access rights are retained property rights and they inhere in specific tribes. Treaty-based resourceaccess rights do not go to "the Indians" as a racial group, but to the specific tribe (such as the Yakima Tribe, or the Chippewa Tribe, or the Navajo Nation, or...) that owns the specific easement retained in its treaty with the United States. To fail to respect those

\footnotetext{
23 U.S. Commission on Civil Rights (2003) at 4.

24 U.S. Commission on Civil Rights (2003) at 1-3.
} 
reserved rights because they inhere in an Indian tribe, rather than in a non-Indian corporation, for example, would be to deny property rights because of race.

In addition, the criticism that tribes represent exclusionary racial groups is misguided. Indian nations determine their own membership, and blood quantum is commonly a factor in this determination. Generally, however, it is the U.S., not the tribe that originated the idea of a blood quantum. Historically, the tribes sometimes took nonIndians in and made them tribal members; it was the United States that refused to recognize those non-Indians as tribal citizens. Today, if a tribe wanted to make a nonIndian a citizen (because, for example, that non-Indian had married a tribal member), it is not clear that federal law would authorize or recognize such citizenship (although no such impediment applies generally to, say, Ohio's right to grant citizenship to a migrant from, say, Georgia upon marriage to an Ohioan).

In fact, the U.S. today employs the racial concept of descent from an historic member of an Indian nation as a crucial criterion for recognition of a group as a tribe by the federal government. It does so to prevent a collection of non-Indians from getting together and calling themselves a tribe. The crucial factor for Indian nations at present is the preservation of existing sovereignty - not the aggrandizement of sovereignty by adding non-Indian members. Similarly, it is federal law that distinguishes between Indians and non-Indians for the purpose of criminal jurisdiction on reservations; the tribes historically did not make such distinctions and repeatedly strive now to overturn such distinctions as they try to govern their reservations. 
The legacy of original federal policy leaves many tribes with race as a criteria of citizenship. Interestingly, this seems to have compelled the current Supreme Court to adopt a "club" theory of tribes under the notion that voluntary clubs may discriminate on the basis of self-selected criteria. At the same time, many tribes are increasingly exercising their sovereign powers by rewriting their original, federally-drafted constitutions. Often at the center of such reform is the establishment of new criteria for citizenship. To be sure, tribes engaged in such reform often struggle with the question of continuing blood quantum criteria for citizenship. For some, this means doing away with blood quantum standards and moving to descendancy or demonstration of knowledge of the tribe's history and culture. Such standards are not unlike those used in the U.S. - as when the children of U.S. citizens automatically are citizens of the U.S., and when new immigrants must learn a modest amount of U.S. history and civics.

The reality, however, is that Indians are not similarly situated to other ethnic and minority groups. Indian nations were the original sovereigns and owners of the land now occupied by the United States. As such, current Indians are inheritors of specific land, resource and other rights and assets, and blood quantum criteria provide a form of, essentially, executing probate. The United States was not formed merely by the Constitution, but by the treaties entered into with Indian nations. Those treaties form the original framework of American government and recognize both tribes' sovereignty and retained property rights. U.S. law respects both property rights and contract rights, as well as international treaties. To fail to honor treaties with Indian nations would take from them property rights recognized by those treaties, constitute breaches of contract, 
and violate the constitutional structure of American government. In asserting sovereignty, Indian nations are not seeking special rights. They are asking that the U.S. to grant the same respect to its commitments to Indian nations that it grants to its commitments made to the other sovereigns that it subsumed upon its formation and expansion (i.e., the states) and to the other sovereigns with whom it has entered into treaties.

\section{II.B The State of Tribes' Sovereignty}

5. “Tribes aren't really nations; they're more like clubs.” In the beginning, tribes were self-governing entities. In 1832, the Supreme Court defined them in Worcester v. Georgia ${ }^{25}$ as "domestic dependent nations" who had complete sovereignty over their members and their territory subject only to overriding federal power. Although physically located within the borders of a state, the Worcester court held that state law had no effect in Indian country. Non-Indians who entered tribal land were subject only to tribal law and to applicable federal laws. Starting in 1978, the Supreme Court has been on a campaign to reduce tribal powers over non-members. In that year it held that Indian nations have no criminal jurisdiction whatsoever over non-Indians. ${ }^{26}$ Three years later, it reversed the Worcester rule and held that tribes generally have no civil jurisdiction over non-members, at least on non-member owned land within reservation borders. ${ }^{27}$

2531 U.S. (6 Pet.) 515 (1832).

26 Oliphant v. Suquamish Indian Tribe, 435 U.S. 191 (1978).

27 Montana v. United States, 450 U.S. 544, 565-66 (1981). 
However, one year later, the Supreme Court affirmed broad tribal regulatory powers over nonmembers who enter tribal land in Indian country. ${ }^{28}$

Since 1982, the Supreme Court has been more and more unwilling to grant Indian nations regulatory powers or court jurisdiction over nonmembers. For example, in 1989, the Supreme Court ruled in Brendale v. Confederated Tribes and Bands of Yakima Nation $^{29}$ that tribes generally have no power to impose their zoning laws on non-Indian owners of land within Indian country, despite the fact that no coherent land use policy or zoning law can exist with checkerboard jurisdiction determined by land ownership. Similarly, the Court held in Strate v. A-1 Contractors that tribes have no power to apply their tort law to lawsuits between non-Indians for car accidents that take place on stateowned roads inside the reservation, even though the tribe has an interest in regulating driving within reservation borders to protect the safety of its own members who drive on the reservation. And in 2001, the Supreme Court ruled in Atkinson Trading Co. v. Shirley ${ }^{30}$ that tribes have no power to impose taxes on non-Indian owners of land inside the reservation even if the tribe provides significant services to the owner. ${ }^{31}$ The final straw was the 2001 case of Nevada v. Hicks ${ }^{32}$ which held that tribes' courts have no jurisdiction over state law enforcement officials who enter tribal land to investigate an off-reservation crime. If interpreted broadly, the Hicks ruling would prevent tribes from asserting any regulatory powers whatsoever over nonmembers even if they trespass on

\footnotetext{
28 Merrion v. Jicarilla Apache Tribe, 455 U.S. 130 (1982).

29492 U.S. 408 (1989).

30532 U.S. 645 (2001).

31532 U.S. 645 (2001).

32533 U.S. 353 (2001).
} 
tribal lands and commits torts or other harms to tribal members at home on their own land unless those nonmembers had expressly contracted to voluntarily submit themselves to tribes' jurisdiction.

Limiting tribal power to tribal members conceptualizes tribes as private clubs or religious organizations. Members of clubs or churches can choose to join and choose to leave at any time. They can enforce their norms on their members only if those members agree to submit to their authority. But tribes are not merely clubs; they are sovereigns domestic dependent nations who never voluntarily relinquished their powers over their territory. Moreover, the treaties and statutes recognizing the reserved rights of tribes implicitly affirm tribal political powers of their retained lands. Despite what the Supreme Court believes, the coerced transfer of property from the tribe to non-Indian owners that occurred in the allotment era from 1887 to the 1934 in no way diminished tribal power over the lands that were conveyed. Tribal sovereignty remained until it was expressly taken away by Congress. Moreover, the Indian Reorganization Act of 1934 repudiated the allotment policy and enacted a new policy in support of tribal government. Although this policy was again reversed in the 1950s, it has been the consistent practice of every Congress and every President since 1960 to support tribes’ sovereignty. Sovereigns have power over territory, not just citizens. The oddness of defining sovereignty by reference to citizenship alone can be seen if one focuses on the result of the Brendale decision described above. The county or city zones land owned by non-Indians, while the tribe applies its zoning law to land it owns and to land owned by its members. If the 
ownership pattern is a checkerboard then no sovereign is capable of enacting a rational land use plan.

The Supreme Court's decisions since the early 1980s bespeaks a worry that tribal courts and tribal councils will be unfair to non-Indians. This is clear from Justice Souter's concurring opinions in the Hicks case itself: The expressed concern with tribal sovereignty over non-members is that tribes are not directly subject to the Bill of Rights; they are regulated only by the 1968 Indian Civil Rights Act. ${ }^{33}$ That Act does impose a version of the Bill of Rights on tribes. However, by interpretation of the Supreme Court in the 1978 case of Santa Clara Pueblo v. Martinez, ${ }^{34}$ there is no right of action in federal court to enforce these civil rights. ${ }^{35}$ Nor is there a right to remove a tribal court case to federal court, as there is in the case of lawsuits in state court that involve federal constitutional questions. Nor is there a right of review, by certiorari or otherwise, in the United States Supreme Court as there is in the case of state supreme court decisions that adjudicate federal questions.

It is possible that tribal courts may be unfair to nonmembers. However, it is also true that state courts may be unfair to tribal members, especially in states where state court judges are elected and subject to political pressure to limit tribes' jurisdiction and property rights. More important, the Supreme Court has interpreted the Constitution as granting Congress plenary power over Indian affairs. It is Congress, after all, that passed

33 Santa Clara Pueblo v. Martinez, 520 U.S. 438 (1997); Indian Civil Rights Act of 1968, 25 U.S.C. $\S \S 1301-1303$ (2000).

34436 U.S. 49 (1978).

35 The sole exception is that there is a right of habeas corpus in criminal cases. But of course, Oliphant held that tribes have no criminal jurisdiction over non-Indians so the only parties protected by this provision are non-member Indians. See Oliphant v. Suquamish Indian Tribe, 439 U.S. 191 (1978). 
the Indian Civil Rights Act and chose not to create a right of action in federal court to review tribal court actions. Under current Supreme Court interpretations of the Constitution, Congress is free de jure to create federal court review of tribal court decisions: If tribes are acting unfairly toward non-Indians, Congress has the power to respond. A non-activist Supreme Court should be more than hesitant to step in to remedy a problem that Congress has not determined to exist. Even if a problem exists, the Supreme Court would not be blocked de facto from creating a limited constitutional right to challenge tribal court actions in federal court to vindicate fundamental constitutional rights. The Court need not act to protect non-Indian rights by stripping tribes entirely of jurisdiction over non-Indians, particularly where this infringement on tribes' sovereignty violates both congressional and executive policy and constitutes a breach of existing treaties.

There is inconsistency in the Supreme Court's worrying about the protection of civil rights from transgressions by tribes and their courts. At a stroke, stripping all tribes of their judicial sovereignty is wholly unwarranted when it has not been demonstrated that all or even many tribes are judicially unfair or otherwise disrespectful of the rights of those who appear before them. Moreover, while state courts frequently are assailed for their failings (see discussion below in item 9), the Supreme Court has generally remained deferential to state sovereignty when non-Indians bring such complaints against the a state. This suggests an unwarranted intentional or unintentional double standard. Indeed, state governments are generally trusted by the Supreme Court to exercise their powers wisely - even when those powers are exercised over racial minorities and Indians. 
In short, the Supreme Courts recent judicial divestment policy suggests that the Court does not trust tribal governments to be sensitive to the rights of non-Indians. This fear is wholly unrealistic - at least as a general matter. The tribes know that at various periods of United States history, the federal government has acted to diminish or abolish tribal government. Tribes know that the Supreme Court has granted Congress plenary power to do this. Tribes have not historically been protected by the Tenth or Eleventh Amendments. Tribes have, in other words, extremely strong incentives to act fairly to non-Indians in their dealings. If they do not, Congress has the power to take away their sovereign powers entirely. The Supreme Court would benefit from the opportunity to observe the high quality of judicial service being rendered by tribal courts throughout the U.S. (see further in item 9 below).

6. "The treaties are out-of-date anachronisms." Many of the treaties upon which specific Indian nations' claims to de jure sovereignty are based are centuries old. Should they be regarded as archaic law - akin to unrevoked law in Texas that prohibits the shooting of buffalo from the second story of a hotel or Michigan law that prohibits a woman from getting her haircut without her husband's permission? ${ }^{36}$ After all, those treaties were struck at a time when the tribes occupied their original homelands and were formidable counterparties to be reckoned with by a younger United States. Perhaps recognition of tribal sovereignty was proper or expedient in its day, but that day has long since passed.

36 http://www.lawguru.com/weird/part01.html;http://www.lawyersonclick.com/articles/art2-nolaugh. htm. 
Such argument certainly cannot withstand scrutiny de recto. The de facto might of the U.S. cannot create claims of rightful subjugation that are defensible on moral principles, and certainly such claims could not be founded on the voluntarist moral principles of its own founding. It is true that many, many Americans have little contact with their fellow Indian citizens and are not taught about tribal governments in their public school education systems (even if they do get the obligatory exposure to American Indian history and culture around Thanksgiving). ${ }^{37}$ Yet, dismissing tribal rights of selfgovernment on the grounds of contemporary irrelevance or superannuation is properly viewed as either a comment on the lack of collective political voice of a group that accounts for less than $1.5 \%$ of the U.S. population, ${ }^{38}$ or as rationalization for covetous interest in Indian tribes' resources and rights. Certainly, to residents of reservations, the contemporary relevance of tribal government is ubiquitously demonstrated - from the badges of a tribe's law enforcement officers to the tribal elections to the need to get a tribal permit to go hunting or fishing. In terms of meeting citizens' needs, it is equally clear that contemporary tribal government is indispensably relevant. As noted above, effective local, tribal self-government has demonstrably shown progress in alleviating the long-standing problems of economic underdevelopment and social distress in Indian Country. Tribal sovereignty may not matter to most Americans in their day-to-day lives, but it matters critically to American Indians.

37 It is telling that the U.S. federal government feels compelled to address the need for broad public education by publishing and answering "Frequently Asked Questions” such as: What is a reservation? Are Indians required to stay on reservations? Are Indians U.S. citizens? Did all Indians speak one language? See Bureau of Indian Affairs (2001).

38 U.S. Census Bureau at http://www.census.gov/population/cen2000/phc-t1/tab04.pdf. 
7. "Even if Indians originally had rights of self-rule, there are no authentic Indians left." Some non-Indians seem to be able to tolerate tribal activity if it fits within a mythological picture of traditional or authentic Indian practice. Thus, a tribe holding a pow-wow seems appropriate, but a tribe operating a casino - or a factory - does not. And it has been argued vociferously that treaty rights may have been called for as part of a paternalistic effort to help poor Indians in prior centuries, but should be extinguished when a tribe is achieves a "moderate standard of living." 39 It is as if Native rights of selfgovernment are held to survive only so long as Indians behave and appear in accord with the dominant culture's icons of "Indianess."

With rights of self-rule founded in de recto principles of primacy and voluntarism, and with de jure sovereignty deriving from the Constitution and the treaties, the argument that tribes lose their claims to sovereignty upon cultural and economic change that makes them appear "modern”, “western (European)”, or otherwise non“authentic" lacks defensible foundation. It would be as if Texas' statehood should now be abolished and the state made a federal district, or absorbed into urbane New York, because Texas no longer holds to its iconic rip-roaring roots. The reality is that tribes develop and change as do non-Indian communities develop and change. So far, as history has recorded, neither the U.S. founding fathers nor the Navajos of the prereservation era played golf; descendants of both now are golf professionals. To have a nation's sovereignty, including a tribal nation's sovereignty, recognized only if it sticks to

39 Notwithstanding such assertion of a "moderate standard of living” doctrine, the Minnesota Chippewa Bands prevailed in seeking to have the Treaty of 1837 upheld in Mille Lacs Band of Chippewa Indians v. Minnesota, 952 F. Supp. 1362 (D. Minn. 1997) (Mille Lacs IV) (PA 74); Fond du Lac Band of Chippewa Indians v. Carlson, unreported, No. 5-92-159 (D. Minn. Mar. 18, 1996) (PA 419). 
"traditional" activities (as "traditional" is defined by another culture) fails to recognize that tribes are alive and functioning as governments and societies, attentive to changing needs and social circumstances and spurred to promote economic, social, political and spiritual development of their own communities.

The view that tribes' rights of self-government are derived from cultural distinctiveness anchored (now largely by mainstream folklore and popular media misrepresentations and caricatures, rather than fact) in a particular historical moment are often related to an assertion that as a tribe's choices and practices change and (at least outward) appearances take on a contemporary mainstream texture, tribal membership becomes a matter of convenience and economic opportunism. That is, tribal membership purportedly becomes a means to tap into a panoply of special rights and economic largesse, rather than "true" cultural and political adherence. ${ }^{40}$ While there are undoubtedly individuals who have sought tribal status for "base" reasons of economic advantage, in so doing, they have repeated the paths of millions of immigrants who have sought U.S. citizenship for reasons of economic advantage. Further, as an attack on authenticity, this critique fails to address the conduct of hundreds of thousands of reservation citizens who choose to remain in their reservation communities in the face of continuing economic deprivation and repeated demonstration that it is moving off the reservation that the holds promise of economic improvement. The bonds of community dominate in such ubiquitous cases.

40 This theme is clearly present in, for example, Bordewich (1996) and Benedict (2000). 
Finally, while changing culture and conduct do not provide a de recto or de facto basis for the extinguishment of tribes' sovereignty at even the extremes of cultural homogenization, it is also true that outsiders to tribal communities sometimes misunderstand seemingly contemporary practices that actually include traditional elements. To the outsider, for example, the fact that Cochiti Pueblo may operate one of the top-rated public golf courses (along with an upscale retirement community) can mask the fact that the community is governed by traditional governing structure that is as remarkable for its non-Western forms as for its embeddedness in intact Cochiti culture. ${ }^{41}$ The appearance at the business meeting of the newly archetypal tribal accountant or lawyer in her business suit may obscure the fact that she is a clan mother and spiritual leader in her tribe.

8. "The U.S. is anti-sovereignty." While it is true that tribal sovereignty is under more or less constant assault, or at least scrutiny, from parties that are hostile or unreceptive, it is not accurate to say that the U.S. federal government or the U.S. Congress or the U.S. courts are in the midst of an unambiguous, orchestrated attack on Indian self-rule. Notwithstanding legal vacillations, changes of administration, and continuing legislative challenges, it remains the case, as it has for almost 30 years, that the basic tenet of federal-tribal relations is a government-to-government relationship. This was given contemporary impetus by the Indian Self-Determination and Education Assistance Act of 1975 (P.L. 93-638), memorialized in a statement of Indian policy by

\footnotetext{
41 Cornell and Kalt (1997b).
} 
President Reagan in 1983, ${ }^{42}$ and set out as an Executive Orders in 1994 and 1998 by President Clinton. ${ }^{43}$ These laws, orders and proclamations show no signs of being rescinded.

To be sure, there are factions and forces that would like to see the termination of tribes as sovereigns. At the same time, however, there are numerous and ardent nonIndian supporters of tribes' sovereignty. Some of these are visible as national figures, and include federal officials, elected office holders, ${ }^{44}$ and major non-profit advocacy and philanthropic organizations. Perhaps the most significant source of non-Indian support, or at least acceptance, of tribes' sovereignty is now coming at the local level as a product of tribes' investments in their practical capacities to self-govern and deliver governmental services competently and comparably to their non-Indian counterparts. Demonstrating that it can meet its own citizen's needs and fulfill governmental responsibilities “just like” any other government commonly defuses opposition to a tribe's assertion of selfgoverning powers. Indeed, de facto exercising of sovereignty by engaging in effective concrete acts of self-government seems to be a primary antidote to ambiguous or even contrary de jure status. The demonstration of competency tends to alleviate concerns that Indian citizens' needs cannot be met by their governments, provides foundation for operational respect by non-Indian governmental counterparts, reduces litigation, provides an “out” for the legal system when overburdened judges seek settlement or dismissal of

42 Indian Policy: Statement of Ronald Reagan, Jan. 24, 1983, reprinted in Prucha (1990) at 301-032.

43 Executive Order of President Clinton: Government-to-Government Relations With Native American Tribal Governments, April 29, 1994, 59 Fed. Reg. 22951 (May 4, 1994); Executive Order of President Clinton: Consultation and Coordination with Indian Tribal Governments, May 14, 1998, 63 Fed. Reg. 27655-57 (May 19, 1998).

44 Wilkins (2002) at Chapter 3. 
cases that threaten to bog the system down in the complicated and vacillating arena of tribal jurisdiction, and yields direct and indirect benefits to private and public non-Indian parties that benefit from effective self-rule by a tribe.

With their strong incentives to highlight the extreme, the negative and the controversial, the media and political demagogues leave impressions of exceeding hostility between tribes and neighboring non-Indian governments. This tends to obscure the rapidity with which tribes are investing in the capacity to govern and to build productive intergovernmental relations. In the process, they strengthen the sovereignty in practice. The examples are numerous and growing, and include such cases as:

- $\quad$ The Swinomish Cooperative Land Use Program is based on memoranda of agreement and understanding between the Swinomish Indian Tribal Community and Skagit County, Washington. ${ }^{45}$ In the wake of Brendale, the program entails a jointly-drafted and adopted county-tribal land use plan that provides a framework for conducting permitting activities within the boundaries of the checkerboarded Swinomish reservation and establishes a regulatory forum for resolving conflicts that arise. Since 1996, both governments have followed a common Comprehensive Land Use Plan and used similar procedures to administer it, exemplifying a mutually beneficial government-to-government relationship.

- $\quad$ The Great Lakes Indian Fish and Wildlife Commission, a tribally-chartered intertribal organization, negotiated a memorandum of understanding (MOU) with the U.S. Forest Service. ${ }^{46}$ The MOU and attendant process recognizes and implements treaty guaranteed hunting, fishing and gathering rights under tribal regulations and establishes a consultation process for management decisions that affect treaty rights in four National Forests located within areas ceded by the Chippewa in the Treaties of 1836, 1837 and 1842.

45 Harvard Project on American Indian Economic Development, “The Swinomish Cooperative Land Use Program,” Tribal Governance Success Stories: Honoring Nations 2000.

46 Harvard Project on American Indian Economic Development, "Treaty Rights/National Forest Memorandum of Understanding: Tribes of the Great Lakes Indian Fish and Wildlife Commission,” Tribal Governance Success Stories: Honoring Nations 2000. 
- $\quad$ The Confederated Tribes of Grande Ronde (Oregon) operate a highly professional and sophisticated intergovernmental and community relations program designed to produce a track-record of success in asserting and defending the Tribes' jurisdiction and operations. ${ }^{47}$ Grande Ronde's contributions to everything from supporting the local library of a non-Indian neighbor community to health care delivery to non-Indians in its health clinic both make the Tribes a good neighbor and allow the Tribes to be seen as a neighbor governed by a capable government.

- $\quad$ The Chippewa Flowage Joint Agency Management Plan is an agreement between the three major governmental owners of the Chippewa Flowage: the Lac Courte Oreilles Band of Lake Superior Chippewa Indians, the State of Wisconsin, and the U.S. Forest Service. It is designed to uphold treaty rights, promote respect for Lac Courte Oreilles ancestors, and protect the natural beauty and productivity of the lake, which is the third largest in Wisconsin. The Plan entails a consensus-based process for coordinating the parties' management activities and usage decisions, specifies fundamental decision-making principles designed to harmonize their respective values and interests, and sets forth common baseline understandings and goals for the future. Not only has this institutionalized agreement achieved coordinated management of the Flowage, but it also acknowledges and promotes respect for Lac Courte Oreilles Band members' grief over the past inundation of their gravesites, homes, and traditional hunting and gathering areas.

- $\quad$ The Pueblo of Sandia has utilized 1987 amendments to the federal Clean Water Act permitting "treatment as state" status for tribes as the basis for promulgating its own water quality standards. ${ }^{48}$ The Sandia Environmental Department gained U.S. Environmental Protection Agency (EPA) approval of its status and standards in the early 1990s and has since been responsible for water quality regulation on the reservation. Sandia's water quality standards are more stringent than those of the State of New Mexico, and the Pueblo's Water Quality Control Officer monitors the water quality for conformance to the standards, advises prospective dischargers of Sandia's discharge requirements, and coordinates pollution control activities with other local, state, and federal agencies. In the process, Sandia-generated

47 Harvard Project on American Indian Economic Development, "Intergovernmental Affairs Department: The Confederated Tribes of Grand Ronde (Grand Ronde, Oregon)" Tribal Governance Success Stories: Honoring Nations 2000.

48 Harvard Project on American Indian Economic Development, "Water Quality Standards: Environmental Department, Pueblo of Sandia,” Tribal Governance Success Stories: Honoring Nations 1999. 
data regarding river pollution levels have given the Pueblo a voice at the table in discussions regarding local water matters and have served as a counterweight to pollution claims made by local dischargers. After years of silence, the program also has led to increased communication and information-sharing between the Pueblo and the State of New Mexico.

These cases share common themes: Notwithstanding a stated federal policy of government-to-government relations with tribes and similar commitments by numerous state governments, making such recognition of tribal sovereignty operationally real falls heavily to the tribes - but it can be done. For many tribes, the legacies of long-standing reliance on, and subjugation to, the federal government include both ingrained practices and outlooks antithetical to self-determination and governmental systems inherited from the days in which the federal government ran most reservation affairs and controlled most reservation employment and resources. Where a tribe's emphasis in defining and asserting "sovereignty" is concentrated solely on making the federal government live up to what the tribe asserts are the federal government's constitutional, treaty and trust obligations, we see the least progress in actually exercising tribal sovereignty successfully. ${ }^{49}$ No matter how improper de recto, the onus in practice is on tribes to assert sovereignty by performing the functions of governments. In doing so effectively, on-the-ground allies in the support of tribes’ sovereignty are recruited.

\section{II.C The Consequences of Tribes' Sovereignty}

9. "Tribes may be sovereign, but their sovereignty produces lawlessness." The U.S. Supreme Court has recently considered whether the state courts may authorize searches of tribal property on tribal land within Indian country without either the consent

49 See, for example, Aoki, Andrew and Daniel Chatman (forthcoming, 2004); Cornell and Kalt (1998). 
of the tribe or the benefit of a search warrant granted by a tribal court. ${ }^{50}$ Many of the briefs urged the Supreme Court to allow such intrusions on tribal property to avoid allowing reservations to become havens of lawlessness. Tribal governments and courts are often seen by non-Indians as oppressive and/or lawless, both because they are not bound by the Bill of Rights and because of stereotypes about tribes and tribal courts.

There are, of course, problems of law enforcement on reservations - just as there are problems of law enforcement in many non-Indian communities around the U.S. Crime statistics for some reservations are, indeed, discouraging, with rates of murder, for example, reaching levels on par with the most violent cities in the U.S. ${ }^{51}$ Attributing such statistics to dysfunctional tribal governments, however, is a factual error. In Indian Country, problems of criminal law enforcement result in large measure from the combined failures of state, federal and tribal governments. While tribal governments have jurisdiction over Indian-on-Indian minor crimes, states have jurisdiction over nonIndian v. non-Indian crimes, while the federal government has jurisdiction over crimes involving Indians and non-Indians, as well as major crimes (such as murder) involving only Indians. Tribes themselves are governed by their own constitutions and laws, as well as the federal Indian Civil Rights Act. Tribes have no criminal powers over nonIndians whatsoever and tribal criminal powers over their members are limited to jail terms of one year; imprisoned individuals have rights to a habeas corpus remedy in federal court.

\footnotetext{
50 Inyo County v. Paiute-Shoshone Indians of the Bishop Community, 123 S.Ct. 1887 (U.S. 2003).

51 U.S. Department of Justice (1997).
} 
As in economic performance and the delivery of other governmental services, tribal assumption of policing and law enforcement activities under contracting and compacting with the federal government for what would otherwise be federal responsibilities appears to improve both the objective performance of policing on reservations and the subjective attitudes of reservation citizens toward police activities. ${ }^{52}$ The reasons for this lie in the improved accountability that accompanies the shifting the locus of control from Washington, D.C. to the local tribal headquarters. At the Gila River Indian Community, for example, tribal control since 1998 is serving a fast-growing reservation population of 17,000 on the south side of the Phoenix metropolitan area. By supplementing the funds otherwise spent by the federal government with tribal funds, Gila River Police Department has been able to significantly expand its staff size, improve conventional police and ranger services, and enhance management information capacities. Through a focus on community policing, it also has developed neighborhood block watch programs, a Citizens Police Academy, and a bicycle patrol/police cadets unit. As a result of these efforts, the Department has sharply improved response time and decreased crime (while the rates for similar crimes have risen in neighboring Phoenix). ${ }^{53}$

Tribal courts come under attack from opponents of tribes’ sovereignty as being inefficient, irresponsible, and/or incompetent. Such assertions, however, are

52 Wakeling, et al. (2001).

53 Harvard Project on American Indian Economic Development, “Assuring Self Determination through an Effective Law Enforcement Program,” Tribal Governance Success Stories: Honoring Nations 2003. 
inappropriately drawn from extreme cases that belie generalization. ${ }^{54}$ Indeed, similar aspersions are cast at states such as Mississippi, West Virginia and Alabama, which are routinely ranked by the U.S. Chamber of Commerce as the worst state court systems in the United States on measures such as judges' impartiality, judges' competence, and fairness. ${ }^{55}$ Just as with tribes, such real-world challenges that these states face argue for improvements in their court systems, not for termination of their sovereignty.

In fact, tribal courts have been targets for major infusions of funding and expertise over the last decade and a half, and the results show in professionalism and outcomes. In the case of the Confederated Salish and Kootenai Tribes of the Flathead Reservation (Montana), for example, investment in the reservations judicial system by the Tribes have resulted in a court system that is regarded as fully competitive with counterparts among non-Indian governments. ${ }^{56}$ Tellingly, the Salish and Kootenai court system is the institutional backbone of a growing private sector economy which is more than holding its own as an attractor of capital in its competition with the State of Montana (which ranked $43^{\text {rd }}$ in the U.S. Chamber's assessment survey of state court systems in 2002). ${ }^{57}$ Not only are reservations such as Flathead changing impressions as to which governments are "third world”, but many are building legal systems that effectively meld traditional and contemporary legal processes to develop tribal law and to apply it evenhandedly to members and nonmembers alike. The results are judicial systems that

54 Such as the infamous case of Burlington Northern Railroad Company v. Estates of Red Wolf and Bull Tail, et al., summarized in Barker (1997) and Henson, Taylor, et al. 2002.

55 Harris Interactive (The Harris Poll) (2003).

56 Cornell and Kalt (1997b).

57 Harris Interactive (The Harris Poll) (2003). 
are innovative and achieve a critical component of any nation's judicial branch legitimacy in the eyes of the people it serves. ${ }^{58}$ Such advances have been the direct result of sovereignty for tribes. That is, the explicit move of federal policy since the mid-1970s toward self-determination for tribes has increasingly manifested itself as attention by tribes to constitutional and judicial reform. This is not surprising. Self-determination has had the predictable effect of improving the accountability of tribal governments to their citizens across many dimensions. ${ }^{59}$ While Congress retains plenary power over Indian nations, and could theoretically pass a law abolishing tribal courts entirely, those nations have enormous incentives to act in ways that appear fair to both Indians and non-Indians. They are increasingly succeeding in this endeavor.

10. "Sovereignty is a shibboleth. Reservations are just welfare states funded by the federal government." Government benefits to Indians are commonly presumed to be welfare payments and Indians are sometimes seen as refusing to work or lazy, like the vaunted myth of the welfare queen. Indians are commonly presumed to not pay taxes, state or federal. Even the advent of gaming, which has dramatically improved the economic status of a relatively small number of the nation's 560+ federally recognized tribes, is seen as a form of economic assistance provided via federal dispensation of “special rights” to Indians.

58 See, for example, the cases of the Navajo Supreme Court (Harvard Project on American Indian Economic Development, "New Law and Old Law Together, Judicial Branch, Navajo Nation” Tribal Governance Success Stories: Honoring Nations 1999) and (Harvard Project on American Indian Economic Development, "Northwest Intertribal Court System” Tribal Governance Success Stories: Honoring Nations 2003).

59 Jorgensen (2000a); Kalt (1996). 
In reality, transfers (payments) by the federal government to Indian nations and to Indians individually either emanate from precisely the same public assistance programs that apply to all U.S. citizens or are based on treaty promises and compensation for takings of land and resources and for other past wrongs. As the federal government explains: "No individual is automatically paid for being an Indian. The Federal Government may pay a tribe or an individual in compensation for damages for losses resulting from treaty violations, for encroachments on Indian lands, or for other past or present wrongs. ${ }^{, 60}$ In addition, Indians pay taxes. As shown in Figure 1, this occurs in the same basic pattern as applies to state-federal tax relations. That is, Indians (and others) who work and reside on a reservation pay applicable taxes; only state income taxes are not applicable (as, e.g., when the State of Connecticut is unable to tax the incomes of Massachusetts residents who live and work in Massachusetts). The applicability of excise (sales) taxes on on-reservation purchases of liquor, tobacco, gasoline and the like to Indians (and others) has been a matter of controversy and litigation. Under such circumstances and with a desire to avoid litigation, states and tribes have negotiated hundreds of state-tribal compacts that variously provide for payment of taxes by Indians, waving of taxes, waving of taxes for purposes of increasing tribal government spending on public programs, and sharing of tax revenues. ${ }^{61}$

60 Bureau of Indian Affairs (2001). In addition, Indian tribes and individuals may receive checks from the federal government for lease or sale of tribal or individual property. This comes as a result of the fact that the federal government serves as trustee (and hence rental/sales) agent for much of such property. Such payments are clearly not "welfare" or "race-based" or "special rights for Indians". and they have historically been made at below-market levels (see U.S. Congress, 1977, esp. at 339).

61 As noted in Figure 1, across at least 18 states, states and tribes have negotiated more than 200 compacts governing the treatment of state excise taxes on cigarettes, gasoline, liquor, automobile 
Tribal governments pay FICA, unemployment, and social security taxes on the earnings of their employees (including employees of tribal gaming operations). Tribal governments do not pay taxes on their revenues, but do make substantial payments in lieu of taxes under the hundreds of tax and gaming compacts. In Oklahoma, for example, in FY 2001, tribes paid Oklahoma $\$ 8.4$ million from tribal collection of tobacco taxes, and Oklahoma and thirty tribes split motor fuel tax collections, with the tribes receiving reimbursement of \$18.4 million.

registration, and the like. Friends Committee on National Legislation (2001). These compacts variously provide for payment of taxes by Indians, waving of taxes, waving of taxes for purposes of increasing tribal government spending on public programs, and sharing of tax revenues. See, e.g., Oklahoma Indian Affairs Commission (2002). 
Figure 1

TAX STATUS OF INDIANS

\begin{tabular}{|c|c|c|c|}
\hline Taxpayer Tax Paid & $\begin{array}{c}\text { Indians Who } \\
\text { Work } \\
\text { On/Live On } \\
\text { Res }\end{array}$ & $\begin{array}{c}\text { Indians Who } \\
\text { Work On/Live } \\
\text { Off Res }\end{array}$ & $\begin{array}{c}\text { Indians Who } \\
\text { Work Off/ } \\
\text { Live On Res }\end{array}$ \\
\hline Federal Income Tax & YES & YES & YES \\
\hline State Income Tax & NO & YES & YES \\
\hline FICA & YES & YES & YES \\
\hline State Unemployment Tax & YES & YES & YES \\
\hline Property Tax & $\begin{array}{c}\text { YES (Fee } \\
\text { Lands)* }\end{array}$ & YES & $\begin{array}{c}\text { YES (Fee } \\
\text { Lands)* }\end{array}$ \\
\hline State Sales Tax** & YES & YES & YES \\
\hline Liquor, Gas \& Cigarette & YES & YES & YES \\
\hline Tax** & YES & YES & YES \\
\hline Motor Vehicle Tax** & Yas & & YES \\
\hline
\end{tabular}

* Fee lands are privately owned lands located within reservation boundaries but not held in trust by the federal government.

** Across at least 18 states, states and tribes have negotiated more than 200 compacts governing the treatment of state excise taxes on cigarettes, gasoline, liquor, automobile registration, and the like. Friends Committee on National Legislation (2001).

SOURCE: Minnesota Indian Gaming Association, http://www.mnindiangaming.com/ template_info.cfm?page=5.

Tribal governments do not pay state or federal income taxes on income from governmental operations, such as the income of a tribal government's gaming enterprise. As such, tribes are akin to the states insofar as, say, California does not pay taxes to neighboring states, tribes, or the federal government on the earnings of its state 
government enterprise (i.e., the lottery). Under IGRA, however, standard compact provisions require tribes to make payments in lieu of taxes, ostensibly to compensate a state for any burden placed by tribal gaming enterprise operations or patrons. These payments are euphemistically referred to as "contributions". In Arizona, for example, a tribe pays $1 \%$ in “contributions” on its $\$ 25$ million in Class III revenues. A sliding payment scale tops out at $8 \% .{ }^{62}$ In New Mexico, tribes currently remit 3\% of the first $\$ 4$ million in annual casino revenues and $8 \%$ on revenues in excess of that amount. ${ }^{63}$ In Michigan, recent compacts require tribes to pay the state $8 \%$ of their electronic video gaming and slot machines profits, and $2 \%$ to municipalities. ${ }^{64}$ The Michigan Gaming Control board estimates that 9 tribes have remitted more than \$325 million to the state over 1993-2003. ${ }^{65}$ Similar rates of de facto state taxation of Indian gaming occur across the U.S.

For a number of tribes, success in the gaming industry is certainly making inroads against the poverty that has historically been uniformly the state of tribal economies. Gaming-derived income for both tribes and tribal employees, however, is highly concentrated in a relatively small number of tribes. The federal National Indian Gaming Commission calculates that, of 561 federally-recognized tribes, 330 had gaming operations as of 2002, and 41 (12\% of the 330) accounted for $65 \%$ of all tribal gaming

62 Arizona Department of Gaming (2003).

63 New Mexico Business Weekly, August 7, 2003 at http://www.bizjournals.com/albuquerque/stories/ 2003/08/04/daily16html.

64 Michigan Gaming Control Board (2003).

65 Michigan Gaming Control Board (2003). 
revenues. The bottom (in terms of revenues) $55 \%$ of gaming tribes (180 of the 330 tribes) account for only about $10 \%$ of all Indian gaming revenues. ${ }^{66}$

Federal law mandates that gaming income realized by tribal governments (after expenses and payments to states) be applied to the improvement of economic and social conditions on the reservations. ${ }^{67}$ Thus, for all tribes, gaming revenues are being applied to the wide range of governmental functions that other sub-federal governments support in their communities. These range from building sewer systems to refurbishing schools, from expanding law enforcement capacity to improving health care services. Threefourths of the gaming tribes apply $100 \%$ of their net gaming revenues to such standard governmental functions, only one-fourth of tribes pay a portion of their revenues to citizens as dividends (known as "per capitas"). 68

Despite the positive contributions to economic status that gaming is bringing to gaming tribes and that federal policies of self-determination have brought to tribes who have developed the capacity to govern themselves effectively, the reality is that Indian Country remains, in the aggregate, quite poor. While the era of self-determination has brought progress, ${ }^{69}$ Indian nations have had a long way to go in terms of their economic development. As indicated in Figure 2, reservation Indians perennially have been the poorest identifiable group in the United States. American Indian/Alaska Native families

66 National Indian Gaming Commission (2003).

67 Indian Gaming Regulatory Act (25 U.S.C. 2710 [Sec. 11]).

68 National Indian Gaming Association (2003). Again paralleling the sovereignty accorded state governments in the U.S. federal system, such per capita payments by tribes mirror payments by the State of Alaska to its citizens from the State's income off of oil and gas properties.

69 See, generally, the research covered in note 1 above. See, also, discussion below in Section III. 
on and off reservation are two-and-a-half times more likely than the average American family to live in poverty, and the situation is worse for families on reservations. It is estimated that reservation Indians' per capita income is only $54 \%$ of the U.S. average. ${ }^{70}$ The indicated sustained low income status of American Indians (and Alaska Natives) is accompanied by a legacy of deficient health, wealth, general social conditions, and civil infrastructure. ${ }^{71}$ It is these deficits that compel tribes' governments to spend so much of their incomes on governmental services.

Figure 2

PERCENT OF FAMILIES BELOW POVERTY LEVEL

\begin{tabular}{|c|c|c|c|c|}
\hline & 1969 & 1979 & 1989 & 1999 \\
\hline Total U.S. & 10.7 & 9.6 & 10.0 & 9.3 \\
\hline White & 8.6 & 7.0 & 7.0 & 7.3 \\
\hline Black & 29.8 & 26.5 & 26.3 & 21.8 \\
\hline All American Indian/Alaska Native* & 33.3 & 23.7 & 27.0 & 23.4 \\
\hline American Indian/Alaska Native on Res & 57 & 43 & 51 & N/A \\
\hline
\end{tabular}

* Data for 1999 are average of 1997-99, per U.S. Census Bureau (2000).

SOURCES: U.S. Census Bureau, Census of 1970, 1980, 1990, 2000; U.S. Department of Agriculture (2002); U.S. Census Bureau (2000).

An assessment of any presumption to the effect that "Indian reservations are just welfare states funded by the federal government” must be grounded in this recognition of the poverty of Indian Country. Certain federal dollars are directly traceable to the

\footnotetext{
70 Gover (1998).

71 Henson, Taylor, et al. (2002).
} 
treaties, which frequently contain obligations on the part of the U.S. government to provide for health and education and, sometimes, housing. In addition, when the U.S. took over tribal lands and invaded tribal territory, it devastated tribal economies. When the U.S. took 98 percent of the land in the continental U.S. from Indian nations, it made certain promises in return. The payments made by the U.S. under its general trust obligation and in various government programs are making good on those promises. Indians and Indian tribes receiving such payments are not welfare recipients; they are the original owners of the land in the United States and the benefits provided by the federal government are properly understood as mortgage payments the U.S. is making in return for rights to use tribal land.

Even such mortgage payments, however, leave the widespread and often desperate needs of Indian Country unmet. In fact, there is a common pattern to federal funding: Payments made to tribes and Indians under applicable programs are disproportionately low when compared to overall funding levels for Americans. This is the central conclusion of the recent intensive study of federal funding by the U.S. Commission on Civil Rights (USCCR), A Quiet Crisis: Federal Funding and Unmet Needs in Indian Country. ${ }^{72}$ The Commission finds, for example:

- $\quad$ All Spending: Per capita federal government expenditures across the total U.S. population rose in current dollars from approximately $\$ 1800$ in 1980 to more than $\$ 4500$ in 2000 . Over the same period, per capita spending across the Native American population fell - from approximately $\$ 3400$ to slightly more than $\$ 3000$. (USCCR at 11)

- Health: Although Department of Health and Human Services (HHS) budget authority for Indian programs (provided on a discretionary basis) rose 33\%

72 U.S. Commission on Civil Rights (2003) 
over FY 1998-2004, the overall HHS discretionary budget rose 58\%. (USCCR at 38) As a share of the HHS discretionary budget, Indian Health Service (IHS) funding by HHS fell from 5.6\% in FY 1994 to 4.4\% in FY 2004. Comparing American Indians to other populations for which the federal government has direct responsibility for health care, per capita spending by IHS in 2003 is $\$ 2,535$. This compares unfavorably to all other comparison groups examined by USCCR, which examined federal health expenditures on Medicare $(\$ 5,915)$, veterans $(\$ 5,214)$, U.S. general public $(\$ 5,065)$, Medicaid $(\$ 3,879)$, and prisoners $(\$ 3,803)$. (USCCR at $43-44)$

- Housing: Native American program funding as a share of all discretionary appropriations of the Department of Housing and Urban Development (HUD) fell from 3.4\% in FY 1998 to 2.3\% in FY 2004. Over that time period, HUD's discretionary budget increased 54\%, while Native American program funding increased just 8.8\%. (USCCR at 56)

- $\quad$ Criminal Justice: After increasing between FY 1998 and FY 2002, U.S. Department of Justice spending on Native American programs declined by approximately 15\% over 2003 and 2004. While the share of Native American funding in the DOJ discretionary budget rose over FY 1998-2004, it rose from the very low level of $0.7 \%$ to the still very low level of $1.2 \%$. (USCCR at 72) A similar pattern appears in the data for the Office of Justice Programs. (USCCR at 74) Police department spending on reservations is only $80 \%$ of spending in comparable rural areas; staffing with officers on reservations is only at about $75 \%-80 \%$ of the levels in comparable U.S. rural areas, and one-fifth to one-fourth the levels attained in comparable U.S. high crime rates. (USCCR at 77, citing Henson, Taylor, et al. $\left.(2002)^{73}\right)$

- Education: The Department of Education's Office of Indian Education accounts for only $0.2 \%$ of the Department's total discretionary budget, and this has held steady over FY 1998-2004. (USCCR at 89) Bureau of Indian Affairs (BIA) schools spend only $50 \%-60 \%$ of the amount that general public schools do on instruction, with BIA instructional spending held down by an extreme need for upkeep on old buildings. (USCCR at 92)

- Rural Development: The U.S. Department of Agriculture (USDA) is largely responsible for rural development and agricultural support. USDA spending on Native American programs has been a miniscule part of its overall budget, varying between $0.001 \%$ and $0.0016 \%$ over FY 1999-2004. (USCCR at 103). Food distribution program spending for Native Americans have declined slightly over this period, from a tiny $0.0025 \%$ of USDA spending on food and nutrition to an even tinier $0.0021 \%$-- notwithstanding

73 The cited data, in turn, are from Wakeling, et al. (2001). 
the fact that Native Americans experience approximately twice the level of food insecurity and hunger as the general population. (USCCR at 108)

- $\quad$ Bureau of Indian Affairs (aggregate): The share of the U.S. Department of the Interior's budget going to its Bureau of Indian Affairs has fluctuated over FY 1998-2004, declining between 2000-02. The share of the BIA's budget going to tribal priority allocations (providing grants to tribal governments for basic services such as child protective services) declined from 42\% in FY 1998 to 35\% in 2002 to a projected 33\% in 2004. (USCCR at 12 )

Far from being "welfare havens”, American Indian reservations in the aggregate are short-changed when it comes to federal dollars. In area after area, and in the face of relatively greater need, federal spending on Native American programs lags behind spending elsewhere in the U.S. Perhaps more than anything else, this reveals the political weakness of a voice that accounts for less than $1.5 \%$ of the U.S. population.

\section{Summary and Conclusions}

Contemporary self-government by Indian tribes in the U.S. is justified on de recto principles of basic civil rights expressed in the founding precepts of the U.S. itself. And tribes' sovereignty is founded de jure on an admirable pattern of basing relationships between the U.S. and the tribes on treaties, ultimately living up to those treaties as binding contracts, the Constitution and its recognition of tribes' as sovereigns, the explicit policy statements of a steady stream of U.S. presidents, and acts of Congress. Imagined insoluble contradictions arising from multiple sovereigns within the boundaries of the U.S., on reflection, describe the quite workable federalist system of multiple sovereigns that structures the relationships between states and the federal government. Unlike the states who joined the Union through constitutional ratification or petitioning for 
statehood, the tribes gave up, or had taken from them, land, resources and freedoms. Where they could, tribes negotiated treaties guaranteeing them reservation of remaining land and assets, and retention of sovereignty.

The era of official federal policies of self-determination and government-togovernment relations over the last three decades has enabled tribes to build up their capacities for self-rule. Under such policies, the strategy of "just doing it" is pushing hard on the de facto boundaries of Indian self-government. With markedly improving capacity and effectiveness, this push by tribes is demonstrating the unremarkable fact that American Indian tribes have the ability to competently and fairly govern themselves and their reservations. Indian sovereignty today is not an archaic or politically-correct notion of the naïve or romantic. It is just the way that tribes are going about building and rebuilding communities that, by the middle of the Twentieth Century, had lived under a system of federal management that left them the most destitute places in the United States.

After centuries of subjugation to federal control, it should not be surprising that newly (re)emerging Indian nations’ steps are unsure and, occasionally, unstable. The reality is that the alternative of termination of tribes' sovereign status is inconsistent with the U.S.'s moral obligations and constitutional/legal principles. The alternative of federal management of reservations, as prevailed until the mid-1970s, was an economic, social and cultural disaster for Indian America, and an expensive mistake for the U.S. government. Self-determination has turned out to be the only policy that the U.S. has found which has shown real prospect of reversing these disasters and mistakes. As such, 
sovereignty holds the prospect of being a win-win strategy for all contending parties. Obviously, tribes are winners by their own standards - as they demonstrate daily by pushing unerringly for self-rule. But states and the federal government stand to gain as well, as tribes make economic and social progress, contribute to their local and regional economies, and take pressure off of state and federal budgets otherwise needed to fight problems of poverty and social disarray. 


\section{References}

Adams, Alyce. 1999. “The Road Not Taken: How Tribes Choose between Tribal and Indian Health Service Management of Health Care Resources.” Unpublished Ph.D. dissertation, Harvard University.

Allain, Jane May 1996. “Aboriginal Fishing Rights: Supreme Court Decisions.” Library of Parliament, Parliamentary Research Branch, http://www.parl.gc.ca/ information/library/PRBpubs/bp428- e.htm\#CONCLUSION(txt).

Aoki, Andrew and Daniel Chatman. Forthcoming, 2004. "An Economic Development Policy for the Oglala Nation.” In What Can Tribes Do II? Strategies and Institutions in American Indian Economic Development. Amy Besaw and Joseph P. Kalt, eds. Los Angeles: American Indian Studies Center, UCLA.

Arizona Department of Gaming. 2003. Tribal Contributions Fact Sheet. http://www. gm. state.az.us/contributions.htm

Barker, Emily. 1997. “Point of Impact.” The American Lawyer, January 1997.

B.C. Treaty Commission. 2003. “Aboriginal Rights.” http://www.bctreaty.net/files_2/ issues_rights.html.

Benedict, Jeff. 2000. Without Reservation: How a Controversial Indian Tribe Rose to Power and Built the World's Largest Casino. New York: Harper, Collins.

Bordewich, Fergus M. 1996. Killing the White Man's Indian. New York: Doubleday.

Bureau of Indian Affairs. 2001. Answers to Frequently Asked Questions. http://www. doi.gov/bia/aitoday/q_and_.html.

Cornell, Stephen, and Joseph P. Kalt. 1992. "Reloading the Dice: Improving the Chances for Economic Development on American Indian Reservations." In What Can Tribes Do? Strategies and Institutions in American Indian Economic Development. Stephen Cornell and Joseph P. Kalt, eds. Los Angeles: American Indian Studies Center, UCLA. 1-59.

-----. 1995. “Where Does Economic Development Really Come From? Constitutional Rule among the Contemporary Sioux and Apache.” Economic Inquiry 33 (July): 402-26. 
-----. 1997a. "Cultural Evolution and Constitutional Public Choice: Institutional Diversity and Economic Performance on American Indian Reservations." In Uncertainty and Evolution in Economics: Essays in Honor of Armen A. Alchian, ed. John Lott. London and New York: Routledge. 116-42.

----. 1997b. "Successful Economic Development and Heterogeneity of Governmental Form on American Indian Reservations." In Getting Good Government: Capacity Building in the Public Sectors of Developing Countries, ed. Merilee S. Grindle. Cambridge: Harvard Institute for International Development. 257-96.

-----. 1998. "Sovereignty and Nation-Building: The Development Challenge in Indian Country Today.” American Indian Culture and Research Journal 22, no. 3: 187214.

-----. 2000. "Where's the Glue: Institutional and Cultural Foundations of American Indian Economic Development.” Journal of Socio-Economics 29: 443-70.

Costello, E. Jane, Scott N. Compton, Gordon Keeler, Adrian Angold. 2003. "Relationships Between Poverty and Psychopathology: A Natural Experiment." Journal of the American Medical Association vol. 290, no. 15. 2023-29.

Dixon, Mim, Brett Lee Shelton, Yvette Roubideaux, David Mather, and Cynthia Mala Smith. 1998. Tribal Perspectives on Indian Self-Determination and SelfGovernance in Health Care Management. Vol. 4. A Report by the National Indian Health Board. Denver.

Ferrara, Peter J. 1998. The Choctaw Revolution: Lessons for Federal Indian Policy. Washington: Americans for Tax Reform Foundation.

Friends Committee on National Legislation. 2001. http://www.fcnl.org/issues/nat/sup/ indians_tribaltax501.htm.

Gover, Kevin (Asst. Secretary - Indian Affairs). 1998. Statement on the FY 1999 Budget Request for the Bureau of Indian Affairs. Washington, D.C.: U.S. Senate, Committee on Indian Affairs. February 25, 1998.

Harris Interactive (The Harris Poll). 2003. 2003 U.S. Chamber of Commerce State Liability Systems Ranking Study. http://www.caltax.org/HarrisSurvey2003.pdf.

Harvard Project on American Indian Economic Development, Tribal Governance Success Stories: Honoring Nations, John F. Kennedy School of Government, Harvard University. 1999, 2000, 2002, 2003. 
Henson, Eric, Jonathan Taylor, et al. 2002. Native America at the New Millennium. Harvard Project on American Indian Economic Development, John F. Kennedy School of Government, Harvard University.

Jorgensen, Miriam R. 1997. “Governing Government.” Unpublished manuscript, John F. Kennedy School of Government, Harvard University.

-----. 2000a. "Bringing the Background Forward: Evidence from Indian Country on the Social and Cultural Determinants of Economic Development." Unpublished Ph.D. dissertation, John F. Kennedy School of Government, Harvard University.

-----. 2000b. “History’s Lesson for HUD and Tribes.” Unpublished manuscript, John F. Kennedy School of Government, Harvard University.

Kalt, Joseph P. 1996. Statement to U.S. Senate Committee on Indian Affairs, Economic Development in Indian Country. September 17, 1996.

Krepps, Matthew B. 1992. "Can Tribes Manage their own Resources? The 638 Program and American Indian Forestry.” In What Can Tribes Do? Strategies and Institutions in American Indian Economic Development, ed. Stephen Cornell and Joseph P. Kalt. Los Angeles: American Indian Studies Center, UCLA. 179-203.

Krepps, Matthew B. and Richard E. Caves. 1994. "Bureaucrats and Indians: PrincipalAgent Relations and Efficient Management of Tribal Forest Resources.” Journal of Economic Behavior and Organization 24, no. 2: 133-51.

Michigan Gaming Control Board. 2003. Tribal-State Gaming Compacts in Michigan. http://www.michigan.gov/mgcb/0,1607,7-120-1380_1414_2182---,00.html.

Moore, Meredith A., Heather Forbes, and Lorraine Henderson. 1990. "The Provision of Primary Health Care Services under Band Control: The Montreal Lake Case.” Native Studies Review 6, no. 1: 153-64.

National Indian Gaming Association. 2003. Indian Gaming Facts.

National Indian Gaming Commission. 2003. Tribal Gaming Revenues. http://www. nigc.gov/nigc/nigcControl?=TRIBAL_REVENUE.

Oklahoma Indian Affairs Commission. 2002. Oklahoma Indian Nations Information Handbook. http://www.state.ok.us/ oiac/hbpages.pdf

-----. 2003. Compacts, Contracts, and Agreements. http://www.oiac.state.ok.us/ cca.html. 
Prucha, Francis Paul (ed.). Documents of United States Indian Policy. Univ. of Neb. Press, 2d ed. 1990.

U.S. Commission on Civil Rights. 2003. A Quiet Crisis: Federal Funding and Unmet Needs in Indian Country.

U.S. Congress. 1977. American Indian Policy Review Commission: Final Report. Washington, D.C.: U.S. Government Printing Office.

U.S. Department of Justice, Executive Committee for Indian Country Law Enforcement Improvements. 1997. Final Report to the Attorney General and the Secretary of the Interior. Washington, D.C.: U.S. Department of Justice.

Wakeling, Stewart, Miriam Jorgensen, Susan Michaelson and Manley Begay. 2001. Policing on American Indian Reservations. Washington, D.C.: U.S. Department of Justice, National Institute of Justice.

Wilkins, David E. 2002. American Indian Politics and the American Political System. Lanham, MD: Rowman \& Littlefield. 